\title{
Perbandingan Efektivitas Povidone lodine 10\% Dengan Sari Kurma Terhadap Lama Penyembuhan Luka Bakar Pada Tikus Putih (Rattus Norvegicus L.) Jantan Galur Wistar
}

\author{
Aldi Prasetya ${ }^{1}$, Ery Suhaymi ${ }^{2}$ \\ ${ }^{1}$ Fakultas Kedokteran Universitas Muhammadiyah Sumatera Utara \\ ${ }^{2}$ Departemen IImu Bedah, Fakultas Kedokteran Universitas Muhammadiyah Sumatera Utara
}

email: aldiprasetya98@gmail.com

\begin{abstract}
ABSTRAK
Luka bakar adalah kerusakan jaringan yang dapat disebabkan oleh panas. Antiseptik yang digunakan oleh masyarakat adalah povidone iodine. Obat sintetik atau yang mengandung zat kimia mungkin menyebabkan efek samping. Masyarakat terkadang juga menggunakan tumbuhan atau buah-buahan dalam upaya penyembuhan luka. Dalam hal ini buah yang digunakan tersebut adalah kurma (Phoenix dactylifera). Kurma mengandung zat yang digunakan sebagai pengobatan yaitu flavonoid dan tannin. Flavonoid sendiri berfungsi sebagai antibakteri, Dan tanin berfungsi sebagai astringen yang dapat menutup pori-pori kulit. Untuk membandingkan efektivitas sari kurma dengan povidone iodine 10\% terhadap lama penyembuhan luka bakar pada tikus jantan. Penelitian ini menggunakan metode eksperimen yaitu rancangan posttest with control group design. Rata-rata kecepatan penyembuhan luka bakar pada povidone iodine 10\% 6,78 hari, sari kurma 9,89 hari dan kontrol 12,56 hari. Terdapat efektivitas pada sari kurma terhadap lama penyembuhan luka bakar pada tikus putih.
\end{abstract}

Kata Kunci: Luka bakar, Penyembuhan luka, Povidone iodine, Sari Kurma

$(\mathrm{cc})$ EY

This work is licensed under a Creative Commons Attribution 3.0 License

\section{PENDAHULUAN}

Luka bakar adalah kerusakan atau kehilangan jaringan yang dapat disebabkan oleh panas (api, cairan/lemak panas, uap panas), radiasi, listrik, atau kimia. Luka bakar merupakan jenis trauma yang merusak dan mengubah berbagai sistem tubuh. ${ }^{1}$ WHO Global Burden Disease, pada tahun 2017 memperkirakan 180.000 orang meninggal akibat luka bakar, dan $30 \%$ pasien berusia kurang dari 20 tahun. Umumnya korban meninggal berasal dari negara berkembang, dan $80 \%$ terjadi di rumah. ${ }^{2}$ Data resmi yang dipublikasikan mengenai prevalensi luka bakar di Indonesia saat ini belum ada namun beberapa data menyampaikan bahwa di Indonesia lebih dari 250 jiwa meninggal per tahun akibat luka bakar. Unit luka bakar RSCM pada 2010 menunjukkan bahwa 60\% luka bakar terjadi karena kecelakaan rumah tangga, $20 \%$ karena kecelakaan kerja, dan $20 \%$ sisanya karena sebab-sebab lain. ${ }^{3}$

Sejauh ini penanganan standar pada luka bakar adalah pemberian antiseptik, antimikroba, dan antiradang. Pengobatan pertama yang dilakukan secara luas adalah menggunakan antiseptik. ${ }^{4} \quad$ Antiseptik yang sering 
digunakan oleh masyarakat luas adalah povidone iodine (PI) yang merupakan kompleks iodine yang mampu membunuh berbagai macam mikroorganisme seperti bakteri, jamur, virus, protozoa, dan spora. ${ }^{5}$

Penggunaan obat-obatan berasal dari zat kimia atau sintetik diyakini oleh masyarakat dapat menyebabkan efek samping. Untuk menghindari obat kimia, masyarakat menggunakan obat-obatan berbahan dasar tumbuhan ataupun buahbuahan. Salah satu buah yang digunakan adalah kurma (Phoenix dactylifera). Kurma mengandung flavonoid dan tanin. ${ }^{6}$ Flavonoid berfungsi sebagai antibakteri, antiinflamasi, dan antioksidan yang apabila diberikan pada luka dapat menghambat perdarahan. Tanin berfungsi sebagai astringen yang dapat menutup pori-pori kulit, menghentikan eksudat, dan menghentikan perdarahan ringan. $^{7}$ Penelitian ini bertujuan membandingkan efektivitas $\mathrm{PI}$ dan sari kurma dalam penyembuhan luka bakar.

\section{METODE}

\section{Rancangan Penelitian}

Penelitian ini menggunakan metode eksperimen dengan rancangan post test with control group. Persetujuan etik atas penelitian ini didapat dari Komisi Etik Penelitian Kesehatan, Fakultas Kedokteran, Universitas Muhammadiyah Sumatera Utara dengan No.331/KEPK/FKUMSU 2019.

\section{Hewan Percobaan}

Hewan percobaan tikus (Rattus norvegicus L.) diperoleh dari Unit Pengelolaan Hewan Laboratorium, Fakultas Kedokteran, Universitas Muhammadiyah Sumatera Utara pada September-Desember 2019. Sebanyak 27 tikus menjadi sampel penelitian ini dengan masing-masing 9 tikus untuk kelompok kontrol (K), kelompok sari kurma (P1), dan kelompok povidone iodine $10 \%(\mathrm{P} 2)$.
Tikus yang diikutsertakan dalam penelitian ini memenuhi kriteria inklusi yaitu dalam kondisi sehat, tidak memiliki kelainan anatomis, berat badan berkisar 150-200 g, dan berumur 2-3 bulan. Sedangkan kriteria eksklusi adalah tikus yang tampak sakit dan mati sebelum atau saat penelitian.

\section{Penilaian Luka Bakar}

Sebelum penelitian dimulai, tikus dikarantina selama 6 hari terlebih dahulu agar terjadi penyesuaian lingkungan. Lalu setiap kelompok tikus akan dianestesi menggunakan lidocaine $2 \%$ dan dicukur bulu punggungnya, selanjutnya diberikan paparan luka bakar seluas 2-3 cm. paparan luka dilakukan dengan menggunakan plat besi ukuran $2 \times 1 \mathrm{~cm}$ yang dipanaskan terlebih dahulu di atas api Bunsen selama 10 detik. Dari hari 0, kelompok kontrol negatif tidak diberikan perlakuan. Pada kelompok kontrol positif diberi povidone iodine, diberikan secara topikal 1 tetes lalu diratakan menggunakan cotton bud satu kali sehari. Dan kelompok perlakuan yang diberikan sari kurma, dilakukan pengolesan sebanyak satu kali sehari menggunakan cotton bud. Luka bakar dibiarkan dengan keadaan terbuka.

Pengamatan luka bakar dilakukan pada hari 0, 1, 7, dan 14. Tanda-tanda penyembuhan dinilai secara makroskopis sesuai skor Nagaoka. ${ }^{8}$

\section{Analisis Data}

Uji statistik dilakukan menggunakan program statistik Statistical Product and Service Solution versi 22.0. Normalitas data diuji dengan Shapiro-Wilk Perbandingan lama penyembuhan luka bakar diuji dengan Kruskal Wallis dan post hoc test Mann-Whitney. Derajat kemaknaan yang digunakan adalah 0,05. 
Tabel 1. Skor Nagaoka

\begin{tabular}{cc}
\hline Parameter & Skor \\
\hline Waktu penyembuhan luka & \\
- Di bawah 7 hari & 3 \\
- Antara 7-14 hari & 2 \\
- Di atas 14 hari & 1
\end{tabular}

Infeksi lokal

- Tidak ada infeksi 3

- Infeksi lokal dengan pus 2

- Infeksi lokal tanpa pus 1

Reaksi alergi

- Tidak ada reaksi alergi

- Reaksi alergi lokal berupa 3

bintik merah sekitar luka $\quad 1$

\section{HASIL}

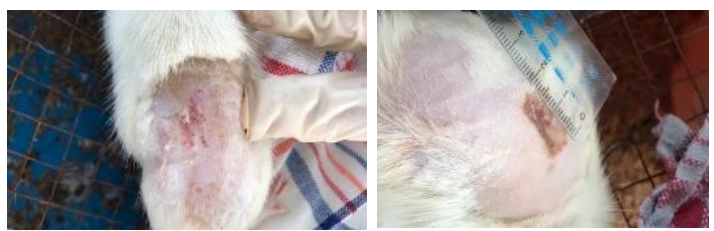

Gambar 1. Kelompok kontrol hari 1 dan 4

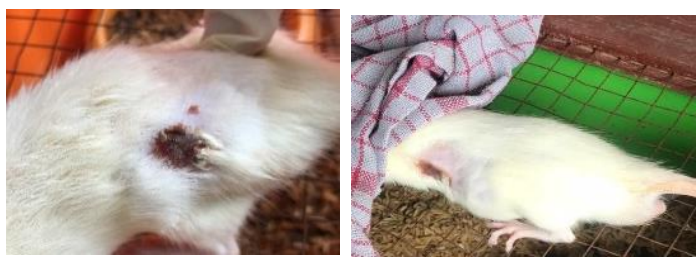

Gambar 2. Kelompok kontrol hari 7 dan 14

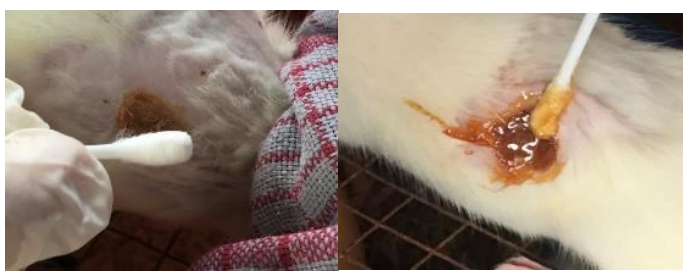

Gambar 3. Kelompok Sari Kurma hari 1 dan 4

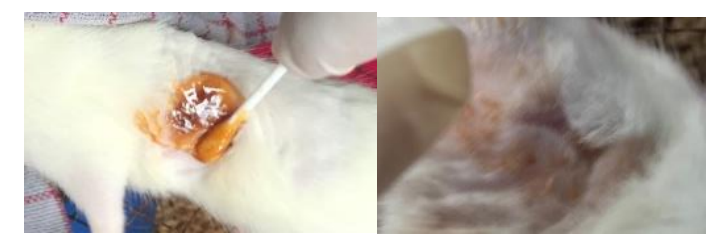

Gambar 4. Kelompok Sari Kurma Hari 7 dan 14

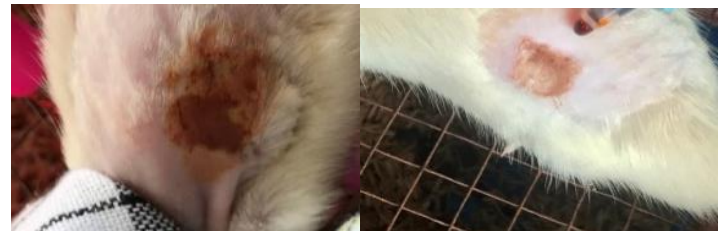

Gambar 5. Kelompok povidone iodine $10 \%$ hari ke 1 dan 4

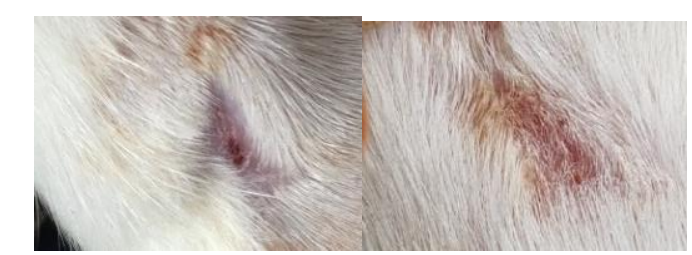

Gambar 6. Kelompok povidone iodine 10\% hari ke 7 dan 14

Tabel 2 menunjukkan bahwa kelompok P2 memiliki waktu tercepat dalam penyembuhan luka (6,78 hari) diikuti oleh kelompok P1 (9,89 hari) dan kelompok kontrol (12,56 hari).

Tabel 2. Lama Penyembuhan Luka Bakar

\begin{tabular}{ccc}
\hline Kelompok & Penyembuhan (Hari) & Std.deviasi \\
\hline Kontrol (K) & 12,56 & 1,130 \\
Sari Kurma (P1) & 9,89 & 2,522 \\
Povidone Iodine (P2) & 6,78 & 1,093 \\
\hline
\end{tabular}

Pada tabel 3 menunjukan P2 memiliki skor makroskopis Nagaoka tertinggi yaitu 8,4 , kemudian diikuti oleh P1 yaitu 8,22 dan kelompok kontrol dengan hasil 7,8 .

Tabel 3. Total Skor Makroskopis Nagaoka

\begin{tabular}{ccccc}
\hline Kelompok & $\begin{array}{c}\text { Infeksi } \\
\text { (Skor) }\end{array}$ & $\begin{array}{c}\text { Alergi } \\
\text { (Skor) }\end{array}$ & Total & Std.deviasi \\
\hline Kontrol (K) & 3 & 3 & 7,8 &, 441 \\
Sari Kurma (P1) & 3 & 3 & 8,22 &, 500 \\
$\begin{array}{c}\text { Povidone Iodine } \\
\text { (P2) }\end{array}$ & 3 & 3 & 8,4 &, 500 \\
& & & &
\end{tabular}

Hasil dari perhitungan skor makroskopis modifikasi Nagaoka terlihat pada tabel 4. 
Tabel 4. Penilaian skor makroskopis Nagaoka

\begin{tabular}{|c|c|c|c|c|c|}
\hline KONTROL (K) & $\begin{array}{l}\text { Penyembuhan } \\
(\text { Hari) }\end{array}$ & $\begin{array}{c}\text { Penyembuhan } \\
\text { (Skor) }\end{array}$ & $\begin{array}{l}\text { Infeksi } \\
\text { (Skor) }\end{array}$ & $\begin{array}{l}\text { Alergi } \\
\text { (Skor) }\end{array}$ & $\begin{array}{c}\text { Total } \\
\text { Skor } \\
\text { Nagaoka }\end{array}$ \\
\hline Tikus 1 & 13 & 2 & 3 & 3 & 8 \\
\hline Tikus 2 & 12 & 2 & 3 & 3 & 8 \\
\hline Tikus 3 & 13 & 2 & 3 & 3 & 8 \\
\hline Tikus 4 & 11 & 2 & 3 & 3 & 8 \\
\hline Tikus 5 & 14 & 1 & 3 & 3 & 7 \\
\hline Tikus 6 & 11 & 2 & 3 & 3 & 8 \\
\hline Tikus 7 & 12 & 2 & 3 & 3 & 8 \\
\hline Tikus 8 & 13 & 2 & 3 & 3 & 8 \\
\hline Tikus 9 & 14 & 2 & 3 & 3 & 8 \\
\hline \multicolumn{6}{|l|}{ Sari kurma (P1) } \\
\hline Tikus 1 & 7 & 2 & 3 & 3 & 8 \\
\hline Tikus 2 & 9 & 2 & 3 & 3 & 8 \\
\hline Tikus 3 & 13 & 2 & 3 & 3 & 9 \\
\hline Tikus 4 & 13 & 2 & 3 & 3 & 9 \\
\hline Tikus 5 & 7 & 2 & 3 & 3 & 8 \\
\hline Tikus 6 & 10 & 2 & 3 & 3 & 8 \\
\hline Tikus 7 & 11 & 2 & 3 & 3 & 8 \\
\hline Tikus 8 & 7 & 2 & 3 & 3 & 8 \\
\hline Tikus 9 & 12 & 2 & 3 & 3 & 8 \\
\hline \multicolumn{6}{|l|}{ PI 10\% (P2) } \\
\hline Tikus 1 & 8 & 2 & 3 & 3 & 8 \\
\hline Tikus 2 & 7 & 2 & 3 & 3 & 8 \\
\hline Tikus 3 & 8 & 2 & 3 & 3 & 8 \\
\hline Tikus 4 & 5 & 3 & 3 & 3 & 9 \\
\hline Tikus 5 & 6 & 3 & 3 & 3 & 9 \\
\hline Tikus 6 & 8 & 2 & 3 & 3 & 8 \\
\hline Tikus 7 & 7 & 2 & 3 & 3 & 8 \\
\hline Tikus 8 & 6 & 3 & 3 & 3 & 9 \\
\hline Tikus 9 & 6 & 3 & 3 & 3 & 9 \\
\hline
\end{tabular}


Uji Kruskal-Wallis menunjukkan perbedaan signifikan dalam lama penyembuhan luka bakar $(p<0,05)$ (Tabel 5).

Tabel 5. Uji Kruskal-Wallis terhadap Lama Penyembuhan Luka

\begin{tabular}{lcc}
\hline \multicolumn{1}{c}{ Kelompok } & Rata-aata dan Std.deviasi & P \\
\hline Kontrol & $12,56 \pm 1,130$ & \\
Sari Kurma (P1) & $9,89 \pm 2,522$ & 0,000 \\
Povidone iodine (P2) & $6,78 \pm 1,093$ & \\
\hline
\end{tabular}

Uji Mann-Whitney menunjukkan bahwa kelompok sari kurma sembuh lebih cepat dari pada kelompok kontrol secara signifikan. Walaupun demikian, kelompok povidone iodine lebih cepat sembuh daripada kelompok sari kurma. (Tabel 6)

\begin{tabular}{lcc}
$\begin{array}{l}\text { Tabel } \\
\text { penyembuhan) }\end{array}$ & Mann-Whitney & (La \\
\multicolumn{1}{c}{ Kelompok } & Uji Mann-Whitney & Keterangan \\
\hline K: P1 & 0,22 & Signifikan \\
K: P2 & 0,000 & Signifikan \\
Pl: P2 & 0,11 & signifikan \\
\hline
\end{tabular}

Uji Kruskal-Wallis menunjukkan total skor modifikasi Nagaoka pada ketiga kelompok tidak berbeda signifikan $(p>0,05)($ Tabel 7).

Tabel 7. Uji Kruskal-wallis disertai Rata-rata dan Std.deviasi (Total skor)

\begin{tabular}{lcc}
\hline \multicolumn{1}{c}{ Kelompok } & Rata-rata & P \\
\hline Kontrol (K) & $7,78 \pm 0,441$ & \\
Sari Kurma(P1) & $8,00 \pm 0,500$ & 0,71 \\
Povidone Iodine (P2) & $8,33 \pm 0,500$ & \\
\hline
\end{tabular}

\section{PEMBAHASAN}

Pada penelitian yang dilakukan pada masing masing kelompok untuk setiap skor infeksi maupun alergi didapatkan hasil yang sama. Untuk total skor modifikasi Nagaoka yang didapatkan seperti keterangan di atas tidak terdapat perbedaan yang signifikan pada masing- masing skor dikarenakan total dari skor tersebut hanya digunakan sebagai indikator penyembuhan luka. Namun apabila dilihat dari rata-rata hasil total skor pada perlakuan total skor povidone iodine lebih tinggi yaitu 8,33 , diikuti oleh sari kurma 8,00 dan kontrol 7,78.

Dalam hal efektivitas lama penyembuhan didapatkan povidone iodine lebih efektif, dibandingkan dengan sari kurma dan juga kontrol. Sehingga walaupun povidone iodine masih lebih efektif, namun sari kurma juga dapat mempercepat lama penyembuhan luka bakar pada tikus saat penelitian.

Sari kurma memiliki banyak kandungan antioksidan seperti alkaloid, flavonoid, tannin maupun vitamin. Sehingga memiliki antiinflamatori sehingga menghambat peroksidasi lemak, enzim siklooksigenase Cox1 dan Cox2. Sehingga antioksidan tersebut diatas dapat berperan penting dalam penyembuhan luka sebagai antiinflamasi. ${ }^{2}$

Sari kurma sangat kaya akan antioksidan fungsi antioksidan adalah menghambat aktivitas dari reactive oxygen species (ROS). ROS mengakibatkan kerusakan sel serta molekul seperti lemak, protein dan DNA. Sari kurma dapat meredakan edema dan juga kemerahan yang terjadi saat inflamasi. $^{10}$

Sari kurma mengandung antimikroba pada jenis bakteri seperti Escherichia coli, Staphylococcus aureus, Enterococcus faecalis, salmonella enterica dan Bacillus subtillis. Kandungan phenolic pada sari kurma menghambat sintesa dinding bakteri serta perkembangannya. Polyphenol juga berperan penting dalam menghambat sintesa protein dan juga menghambat aktivitas enzim pada bakteri. Dengan demikian sari kurma menjadi buah yang potensial untuk digunakan sebagai antibakteri alami. ${ }^{11}$

Penggunaan sari kurma sebagai obat pada luka sayat mendapatkan hasil 
bahwa sari kurma efektif dalam penyembuhan luka. ${ }^{3}$ Fungsi flavonoid adalah antibakteri, antiinflamasi serta antioksidan ada luka dapat menghambat perdarahan. Tanin berfungsi sebagai astringen yang dapat menutup pori pori kulit, menghentikan eksudat, dan menghentikan perdarahan ringan. $^{7}$

\section{KESIMPULAN}

Sari kurma dapat mempersingkat lama penyembuhan luka bakar pada tikus dibandingkan dengan kelompok kontrol namun masih lebih lama daripada povidone iodine $10 \%$. Sehingga sari kurma dapat dipertimbangkan sebagai salah satu alternatif pada penyembuhan luka bakar.

\section{DAFTAR PUSTAKA}

1. Jose L. Anggowarsito. Luka Sudut Pandang Dermatologi. J Widya Med Surabaya. 2014;2. doi:10.1080/0037731650951734

2. Y M. Protokol Unit Luka Bakar RSCM. Jakarta Balai penerbit FKUI. 2007.

3. Rismana E, , Idah Rosidah, Prasetyawan $Y$ OB, $Y$ dan E. Efektivitas Khasiat Pengobatan Luka Bakar Sediaan Gel Mengandung Fraksi Ekstrak Pegagan Berdasarkan Analisis Hidroksiprolin Dan Histopatologi Pada Kulit Kelinci. Bull Heal Res. 2013;41(1 Mar):45-60. doi:10.22435/bpk.v41i1Mar.3058.45-60

4. Kusmawati $\mathrm{Y}$, Kurniaty N, Amir Musadad Miftah. Uji Aktivitas Antibakteri dari Sediaan Antiseptik Povidon-lodine Menggunakan Metode Kontak. 2016;2:516-520.

5. Bigliardi PL, Alsagoff SAL, El-Kafrawi HY, Pyon JK, Wa CTC, Villa MA. Povidone iodine in wound healing: A review of current concepts and practices. Int $J$ Surg. 2017;44:260-268. doi:10.1016/j.ijsu.2017.06.073

6. Benmeddour Z, Mehinagic E, Meurlay D Le, Louaileche $\mathrm{H}$. Phenolic composition and antioxidant capacities of ten Algerian date (Phoenix dactylifera L.) cultivars: A comparative study. J Funct Foods. 2013;5(1):346-354.

doi:10.1016/j.jff.2012.11.005

7. Ningtyas PAS. the effect of ethanol extract of cocor bebek (kalanchoe pinnata (Lam) Pers.) Leaves on White Rats Burn Wound Degree II Healing. Perpust UNS. 2012.

8. T.Nagaoka, Y.Kaburagi, Y.hamaguchi, M. Hasegawa, M. Takehara. K. Steeber, D.A. et. al. Delayed wound healing in the absence of intercellular adhesion molecule1 or L-selectin expression. Am. J. Pathol. 2000;157(1):237-247.

9. Ahmed A, Bano N, Tayyab $M$. Phytochemical and Therapeutic Evaluation of Date ( Phoenix dactylifera ). A Review. J Pharm Altern Med. 2016;9(November 2015):11-17. doi:10.1016/01672584(84)90346-3

10. Ali Haimoud S, Allem R, Merouane A. Antioxidant and Anti-Inflammatory Properties of Widely Consumed Date Palm (Phoenix Dactylifera L.) Fruit Varieties in Algerian Oases. $J$ Food Biochem. 2016;40(4):463-471 . doi:10.1111/jfbc. 12227

11.El-Sohaimy $\mathrm{S}$ a, Abdelwahab a E, Brennan CS, Aboul-enein a M. Phenolic content, antioxidant and antimicrobial activities of Egyptian date palm (Phoenix dactylifera L.) fruits. Aust J Basic App/ Sci. 2015;9(1):141148.

http://ajbasweb.com/old/ajbas/2015/141147.pdf.

12. Miftah dinda nawa. Perbandingan Efek Povidone lodine Dengan Sari Kurma Terhadap Penyembuhan Luka Sayat Pada Mencit (MUS Musculus). Repositori.umsu.ac.id. 